BRUNO ANTULOV-FANTULIN, mag.ing.aeronaut. ${ }^{1}$

(Corresponding author)

E-mail: bruno.antulov@fpz.unizg.hr

BILJANA JURIČIĆ, Ph.D. ${ }^{1}$

E-mail: biljana.juricic@fpz.unizg.hr

TOMISLAV RADIŠIĆ, Ph.D. ${ }^{1}$

E-mail: tomislav.radisic@fpz.unizg.hr

CEM ÇETEK, Ph.D. ${ }^{2}$

E-mail: ccetek@eskisehir.edu.tr

${ }^{1}$ University of Zagreb

Faculty of Transport and Traffic Sciences

Department of Aeronautics

Vukelićeva 4, 10000 Zagreb, Croatia

2 Eskişehir Technical University

Faculty of Aeronautics and Astronautics

Department of Air Traffic Control

İki Eylül Kampüsü, Tepebaşı, Eskişehir 26470, Turkey
Traffic Management Original Scientific Paper Submitted: 14 Nov. 2019 Accepted: 20 Feb. 2020

\title{
DETERMINING AIR TRAFFIC COMPLEXITY - CHALLENGES AND FUTURE DEVELOPMENT
}

\begin{abstract}
Air traffic complexity is one of the main drivers of the air traffic controllers' workload. With the forecasted increase of air traffic, the impact of complexity on the controllers' workload will be even more pronounced in the coming years. The existing models and methods for determining air traffic complexity have drawbacks and issues which are still an unsolved challenge. In this paper, an overview is given of the most relevant literature on air traffic complexity and improvements that can be done in this field. The existing issues have been tackled and new solutions have been given on how to improve the determination of air traffic complexity. A preliminary communication is given on the future development of a novel method for determining air traffic complexity with the aim of designing a new air traffic complexity model based on air traffic controller tasks. The novel method uses new solutions, such as air traffic controller tasks defined on pre-conflict resolution parameters, experiment design, static images of traffic situations and generic airspace to improve the existing air traffic complexity models.
\end{abstract}

\section{KEY WORDS}

air traffic complexity; air traffic controller; assessment; workload; tasks;

\section{INTRODUCTION}

The growth in traffic demand is a driver of air traffic development but it could also lead to negative consequences such as airspace congestion, flight delays, high traffic density, flight inefficiency due to excessively long routes, increased fuel consumption, and therefore, increased flight costs and environmental impact. These problems will become even more pronounced in the coming years, due to the increased traffic demand.

The trend of air traffic growth in the EUROCONTROL zone from 2013 continued until 2018, after a few years of stagnation caused by the global economic crisis. The number of flights based on instrument flight rules (IFR) grew by $3.8 \%$ on average compared to the traffic in 2017. The air traffic growth is larger in terms of passenger numbers than in terms of flights (6.1\% compared to 2017), which was also the case in the preceding years [1]. This growth continued in the first half of 2019, with the number of controlled flights in the EUROCONTROL zone increasing by $1.6 \%$ on average, compared to 2018 [2]. According to the EUROCONTROL medium-term forecast, it is estimated that the growth of IFR traffic will continue in the following years to the year 2025 with the average annual growth of $2.0 \%$ [3].

In such conditions, more complex air traffic situations occur which may impede the provision of air traffic control service, in particular, specific air traffic controller tasks. This can result in increased air traffic controller workload that poses a potential safety hazard. To meet the traffic demand, air navigation service providers must ensure adequate sector capacity that will allow safe and efficient air traffic. Since the sector capacity depends on the air 
traffic controller workload, air traffic complexity becomes one of the crucial factors that is considered when investigating these indicators and the air traffic management system. Air traffic complexity is defined as the difficulty of monitoring and managing a specific air traffic situation [4].

The Single European Sky (SES), which is the project of modernizing and improving the European air traffic management, aims to increase the traffic safety, capacity and efficiency as well as to reduce the negative consequences of increased air traffic demand. Several new technologies (solutions) have been developed through SES air traffic management research (SESAR) program to meet the high traffic demand and to ensure traffic safety. Air traffic complexity is investigated and researched within the SESAR which resulted in the SESAR Solution\#19 Automated Support for Complexity Detection and Resolution (from SESAR 1). One of the sub-functionalities to be developed within SESAR2020 is Automated Support for Traffic Complexity Assessment which is prescribed in the Commission Implementing Regulation (EU) No. 716/2014 of 27 June 2014 on the establishment of the Pilot Common Project supporting the implementation of the European Air Traffic Management Master Plan.

This paper gives the research overview of models and methods for determining and assessing air traffic complexity. Based on previous research findings, we identified the shortcomings on the existing models, presented a novel method for determining air traffic complexity and proposed a new model that should surpass the flaws that are still present in this field of research.

\section{AIR TRAFFIC COMPLEXITY AND AIR TRAFFIC CONTROLLER WORKLOAD}

Air traffic complexity has been a common research topic since the early days of modern air traffic control (ATC) operations. At the beginning, most of the research dealt with the air traffic controller (ATCO) workload instead of air traffic complexity to express how difficult some ATCO tasks were. Because of that, it is important to explain the relation between these two indicators. The first papers that dealt with the complexity were written in the early 1960s [5]. Since then, numerous papers and reports have been written on the topic of complexity - excellent reviews of those papers were written by Mogford [6] and Hilburn [7]. Their conclusion was that the air traffic complexity is a fundamental driver of workload but that the connection between complexity and workload is not straightforward; it is mediated by other factors, such as equipment quality, individual differences, and controller cognitive strategies (Figure 1) [6]. It can be noticed that most of the early research has been conducted in order to better define the factors that affect air traffic controller workload. From today's point of view and with present understanding and definitions, the majority of these factors would probably be classified as complexity factors.

Schmidt [8] approached the problem of modelling controller workload from the angle of observable controller actions. He created the control difficulty index, which can be calculated as a weighted sum of the expected frequency of occurrence of events that affects the controller workload. Each event is given different weight according to the time

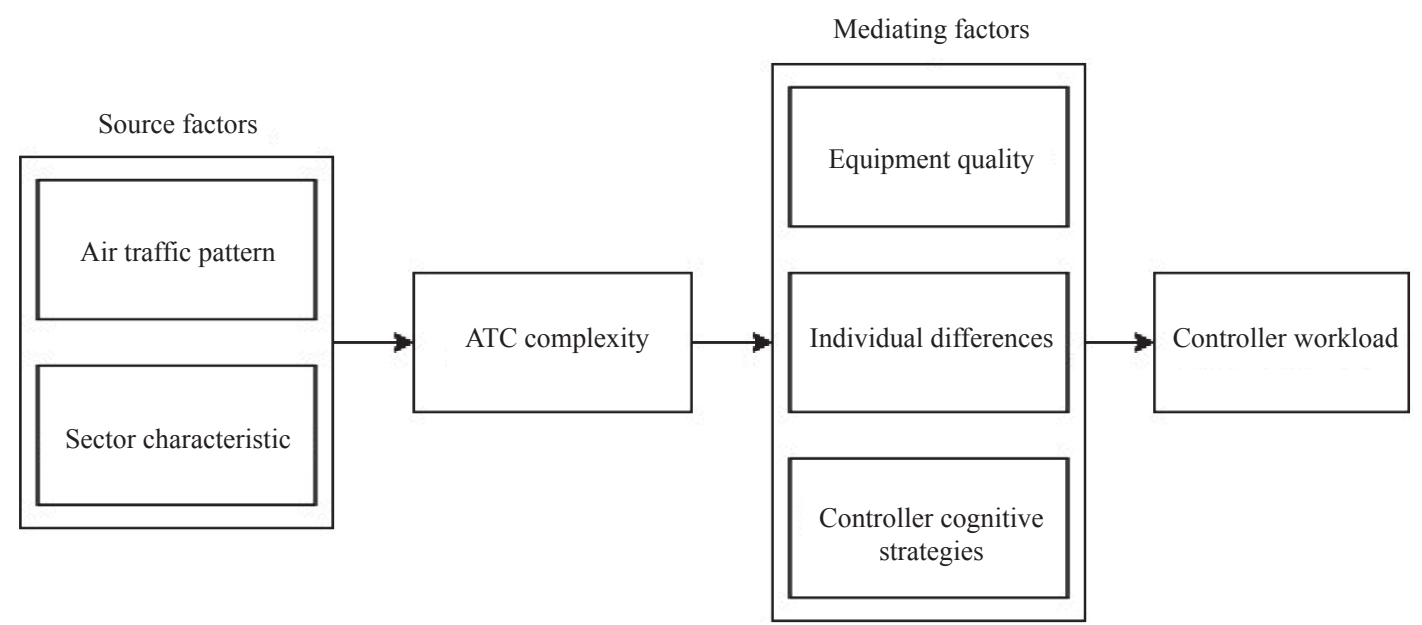

Figure 1 - Relationship between ATC complexity and workload [6] 
needed to execute a particular task. Although the author conducted extensive surveys to determine the appropriate weights and frequencies for various events, this approach can only handle observable controller actions, which makes this approach very limiting.

Even though Hurst and Rose [9] were not the first to realize the importance of traffic density, they were the first to measure the correlation of expert workload ratings and the traffic density. They concluded that only $53 \%$ of the variance in the reported workload ratings can be explained by density.

Stein [10] used the Air Traffic Workload Input Technique (ATWIT), in which the controllers report the workload levels during simulation, to determine which of the workload factors influenced the workload the most. The regression analysis proved that out of the five starting factors, four factors (localized traffic density, number of handoffs outbound, total amount of traffic, number of handoffs inbound) could explain $67 \%$ of the variance in ATWIT scores. This study showed the importance of localized traffic density which is a measure of traffic clustering. A technique similar to ATWIT is to be used throughout the next three decades.

\section{OVERVIEW OF AIR TRAFFIC COMPLEXITY MODELS AND METHODS}

Today, air navigation service providers still use air traffic controllers' subjective assessment as the most important method for determining the air traffic complexity, even though there are many studies that have dealt with the development of new, more objective methods for determination of air traffic complexity. The most important scientific papers dealing with the methods and models for determining air traffic complexity are based on the subjective assessment by the air traffic controllers.

Laudeman et al. [11] expanded on the notion of the traffic density by introducing Dynamic Density which they defined as a combination of 'both traffic density (count of aircraft in a volume of airspace) and traffic complexity (a measure of the complexity of air traffic in a volume of airspace)'. The authors used informal interviews with controllers to obtain a list of eight complexity factors to be used in the dynamic density equation. The only criterion was that the factors could be calculated from the radar tracks or their extrapolations. The intention was to obtain an objective measure of controller workload based on the actual traffic. Their results showed that the dynamic density was able to account for $55 \%$ of controller activity variation. Three other teams [12-14] working under the Dynamic Density programme developed additional 35 complexity indicators (factors), which were later successfully validated as a group by Kopardekar et al. [15]. Unfortunately, it was later shown that the complexity indicator weights were not universal to all airspace sectors, i.e. they had to be adjusted on a sector by the sector basis [16]. While making Dynamic Density technique difficult to implement for operational purposes, this shortcoming has no influence if one wishes to compare two concepts of operations under similar conditions (similar sector configuration). Furthermore, the same authors [15] suggested that, due to possibly non-linear interactions between complexity factors, the Dynamic Density performance could be improved by using non-linear techniques such as non-linear regression, genetic algorithms, and neural networks.

Almost the same group of authors will use multiple linear regression method five years later to determine which subset of complexity indicators would correlate well with the controller's subjective complexity ratings [17]. After extensive simulator validation, the results of this study showed that there were 17 complexity indicators that were statistically significant. The top five complexity indicators were: sector count, sector volume, number of aircraft under $8 \mathrm{NM}$ from each other, convergence angle, and standard deviation of ground speed/mean ground speed. Similar work was done by Masalonis et al. [18] who selected a subset of 12 indicators, and Klein et al. [19] who selected a subset of only seven complexity indicators, though with less extensive experimental validation.

In a similar vein, Bloem et al. [20] tried to determine which of the complexity indicators had the greatest predictive power in terms of future complexity. The authors concluded that there was a significant difference in the predictive power of different complexity indicators. To complicate the matter further, they concluded that the subset of the complexity indicators that had the best predictive power changed depending on the prediction horizon.

To calculate the potential impact of air traffic complexity on the workload and costs, in 2000 EUROCONTROL gave the same set of traffic data to the UK National Air Traffic Services (NATS) and EUROCONTROL Experimental Centre (EEC) with 
the task of independently devising a method of measuring the level of service [21]. While NATS estimated the ATS output (the service provided), the EEC estimated the ATS workload needed to deliver the service. Both 'were found to produce reasonably consistent results', with additional note that further analysis should be done before the final parameters for determining ATS provider costs are established. By 2006 EUROCONTROL Performance Review Commission finalized the complexity indicators to be used for ANSP benchmarking [22]. For this method the European airspace is divided into 20 NM X 20 NM X $3000 \mathrm{ft}$ cells, and for each cell the duration of potential interactions is calculated. The aircraft 'interact' if they are in the same cell at the same one-hour timeframe window. The ratio of the hours of interactions and flight hours is so called 'Adjusted Density'. In addition, the 'Structural Index' is calculated as a sum of potential vertical, horizontal, and speed interactions. The final complexity score is calculated as a product of adjusted density and structural index. All in all, only four complexity indicators were used for this analysis and no validation of any sort was presented in the report. It was noted, however, that shifting the starting position of the grid by 7 NM caused the ANSP ranking to change dramatically (up to 16 places in an extreme case). Nonetheless, this method is still used for ANSP benchmarking.

The first to consider measuring complexity during trajectory-based operations (TBO) were Prevot and Lee in 2011 [23]. They coined the term Trajectory-based Complexity (TBX) which is a measure of complexity in TBO. The basis of the TBX calculation is a set of nominal conditions - nominal sector size, nominal number of transitioning aircraft, and a nominal equipage mix. Any difference to nominal operations causes a modification to the TBX value. The authors do not explain the method to determine the nominal conditions except that they can 'be defined through knowledge elicitation sessions on a sector-by-sector basis or based upon more generic attributes'. The TBX value is then a number of aircraft that would produce the same workload under the nominal conditions as do aircraft under real conditions (e.g. the TBX of 20 means that the workload is equal to the aircraft count of 20 under nominal conditions even though there are actually only 16 aircraft in the sector). The advantage of this method is that it gives a single complexity value that can be easily related to aircraft count and is thus very user-friendly and self-explanatory (unlike many other complexity metrics). However, this study included only six complexity indicators with weights that were determined in an ad-hoc manner and hardly any validation with actual subjective complexity. Only one of those complexity indicators was indirectly related to TBO (number of aircraft with data-link). Many Human-In-the-Loop (HITL) simulation runs were performed in which the controllers had to give workload scores which were then compared with TBX value and simple aircraft count. While the authors claim that the subjective workload score correlated better with the TBX value, there was no objective correlation assessment presented. Finally, the authors did not compare the effect of the fraction of TBO aircraft on air traffic complexity.

In a subsequent paper by the same authors, the relationship between workload and data-link equipage levels was explored [24]. It was concluded that the workload ratings correlated much better with the TBX score than with the aircraft count for varying data-link equipage levels.

Another study of the complexity of TBO was made by Radišić et al. [25]. The authors investigated how transitioning from conventional to trajectory-based operations affects the air traffic complexity for the area radar air traffic control. They developed a series of scenarios and simulated the conditions of different traffic loads. They used licensed air traffic controllers to implement HITL simulations. During the simulation, the controllers assessed the complexity of the traffic situation on a scale from 1 to 7 (modified ATWIT grading scale). The authors proved that the subjective air traffic complexity has significantly decreased in trajectory-based operations. It has been experimentally demonstrated that the decrease in air traffic complexity was significant only in traffic situations with a larger number of aircraft and with a larger share of aircraft flying in accordance with TBO.

Prandini et al. developed a new method of mapping complexity based exclusively on traffic density [26]. This method is applicable only to the future concept of aircraft self-separation and does not take into account the human factors at all.

Gianazza [27-29] proposed a method for the prediction of air traffic complexity using tree search methods and neural networks. This method is based on the assumption that the air traffic complexity in historical flight data increased prior to the splitting 
of the collapsed sector into two smaller ones and decreased prior to collapsing the sectors into a larger one. The neural network was trained using these historical data and then it could predict the future increase in air traffic complexity. Tree search method was then used to determine the airspace configuration which yields the lowest workload and complexity for the given air traffic pattern.

Lee et al. [30] proposed that airspace complexity can be described in terms of how the airspace (together with the traffic inside it and the traffic control method) responds to disturbances. The effect of disturbances on control activity needed to accommodate that disturbance is what defines the complexity in their opinion. The more control activity needed, the more complex is the airspace. They proposed a tool, airspace complexity map, which should help to plan the airspace configuration and the future development of ATM.

Wee et al. [31] developed a dynamic tactical complexity model, known as Conflict Activity Level (CAL) that evaluates the likely aircraft flight shape profile based on its current and projected position and trajectory. From the flight shape profile, CAL values are computed and the overall complexity score is given. The authors state that the proposed complexity approach shows good agreement with other methods in terms of ranking the order of complexity of various air traffic scenarios.

Dervic and Rank [32] used the comparison method while interviewing the ATCOs to develop a formula that is capable of calculating traffic complexity in the terminal area. The first group of answers, taken from questioning the ATCOs, studied the complexity of the scenarios individually and ranked the scenarios in reference to each other. Those answers were used to make the formula by linear regression models and the second group of ATCOs was used to validate the same formula. Despite the small amount of data samples, the authors were able to prove a genuine relation between the variables and the traffic complexity.

Wang et al. [33] constructed a dynamic weighted network by considering aircraft, waypoints, and airways as nodes, and the complexity relationships among those nodes as edges. The complexity is defined as the sum of the weights of all edges in the network and the results indicate that the new complexity index is more accurate than the traffic count. Thus, the complexity-based management is more efficient than the traffic count-based management.
Xiao et al. [34] developed ATCEM - an air traffic complexity evaluation model that consists of three elements: selected complexity factors as input data, air traffic complexity level as output data and classifier for mapping relationship between the complexity factors and the complexity level. In this model, seven critical complexity factors are selected from the complexity factor pool by a genetic algorithm. The model was trained according to the aviation domain knowledge and using the backpropagation neural network (BPNN) and a large sample data. Although ATCEM was positively empirically evaluated, the authors suggest further research and model improvement by building more effective integration method that would increase the classification performance of air traffic complexity.

Similar work was done by Xi ZHU et al. [35]. The authors proposed a new model to measure air traffic complexity based on small samples. The authors generated multiple small-size complexity factor subsets from the complexity factor pool and used an improved machine-learning model - random subspace to train the model. The basic complexity evaluator was built according to each factor subset. The final complexity measure was obtained by integrating all the results from the basic complexity evaluators. Although the model's performance was experimentally evaluated and showed advantages comparing to other small-sample complexity models, the authors proposed a model improvement by optimizing some parameters and using the semi-supervised machine-learning techniques.

Andraši et al. [36] proved that artificial neural networks (ANNs) can be used to determine air traffic complexity with the accuracy similar to the linear models. They conducted the human-in-theloop experiments with licenced air traffic controllers and concluded that the remaining variance in subjective complexity scores cannot be explained by traffic characteristics. Also, they stated that one of the problems for the errors were inconsistent ATCOs grading of traffic situations. ATCOs could not score (rate) traffic situations with perfect consistency among themselves or between different traffic situations.

\section{ISSUES AND NEW SOLUTIONS}

The problem of determining an adequate complexity score is still an issue in air traffic control, because it is considered subjectively, from the air traffic controllers' perspective. The air traffic 
controllers observe and analyse the traffic data and decide whether a traffic situation is complex or not. All other methods are just attempts to approximate the level of complexity according to air traffic controllers' subjective assessment.

Whether it is a purely mathematical model that does not take into account the controllers' assessment of complexity [22] or a fully human in-theloop testing with linear regression and artificial networks $[25,36]$, the problem of adequate complexity determination is still present. As traffic increases every year, the complexity determination will become even more important since it influences the controller's workload and airspace capacity.

Having this in mind, we propose a novel method when determining air traffic complexity. It can be seen that all existing methods and models for determining air traffic complexity fall short in one of the categories. Whether it is the lack of data gathered for the machine-learning [35] or artificial networks [34], or it is simply that some models are tied to the specific airspace or to the exact personnel on whom they were tested, all this makes the model unusable for adequate complexity determination when trying to use it on different airspace and other ATCO personnel $[16,25]$. Finally, there is a problem of inconsistent complexity assessment by the controllers when the same controller assesses different levels of traffic complexity with the same score of complexity [36].

To mitigate all the problems mentioned above, a development of a new methodology is proposed as well as a novel complexity model that is based on air traffic controller tasks. The air traffic controller tasks are defined on the basis of characteristics of the air traffic situation and do not depend on the person controlling the air traffic. Because of this, we believe that by defining a set of air traffic controller tasks (Figure 2) based on the pre-conflict resolution parameters, the model could calculate an adequate complexity score. Pre-conflict resolution parameters would consist purely of the aircraft geometrical parameters, such as the distance between the aircraft, distance to conflict point, converging angle, aircraft speed, aircraft movement freedom in the airspace, etc. The tasks so defined would be applicable to other airspaces and would not be tied to the specific air traffic controller. Additionally, to ensure the possibility that the model can be used in different airspaces, the traffic situations will be defined in a generic airspace (Figure 2) to avoid air traffic controller's subjective assessment for the already known traffic situations and airspaces. However, the problem of inconsistent assessment of traffic situations, where the same ATCO assesses the traffic situation that has a different complexity level with the same complexity score, still persists. To solve this, we will approach the problem by giving the air traffic controllers two traffic situations at the same time. In our experiments, ATCOs will only evaluate the complexity by comparing the two presented traffic situations. Upon selecting which one of the two presented traffic situations is more complex, they will receive a set of two new traffic situations for complexity assessment. In many previous studies the authors used HITL simulations to assess the air traffic complexity. By using this method, it was difficult for ATCOs to distinguish and assess air traffic complexity from the workload [6]. To eliminate this, the traffic situations will be presented and given to ATCOs by paper static images. The images will be similar to a radar image of the real ATCO working position. All air traffic situations will be designed to contain a specific number of aircraft in different positions that would influence the activation of the appropriate combination of air traffic controller tasks. There will be 120 unique traffic situations developed and divided into six groups (Figure 2). Each group will consist of 30 traffic situations from which 18 will be unique to that group and 12 traffic situations will be the same and repeated in all six groups. The repeated traffic situations are created intentionally in order to better evaluate the ATCO assessment. There will be three air traffic controllers per group, so in total 18 ATCOs will be tested. This design approach is developed to cover the necessary machine-learning sample size. Prior to the experiments we are aware of the following effects; firstly, the number of air traffic controllers and their labelling capabilities are limited; secondly, we are using statistical regularities for the minimum number of samples as a function of independent variables in regression studies [37, 38]. As stated by Green in 1991, the required regression sample size should be $N>50+8 \mathrm{~m}$, where $m$ is the number of independent variables. Furthermore, the authors [38] stated that the statistical power is directly derived from the sample size and effect size. A larger sample size results in increased statistical power, but then again without good effect size, it does not matter how big the sample size is or which rule of thumb formula is to be taken to 


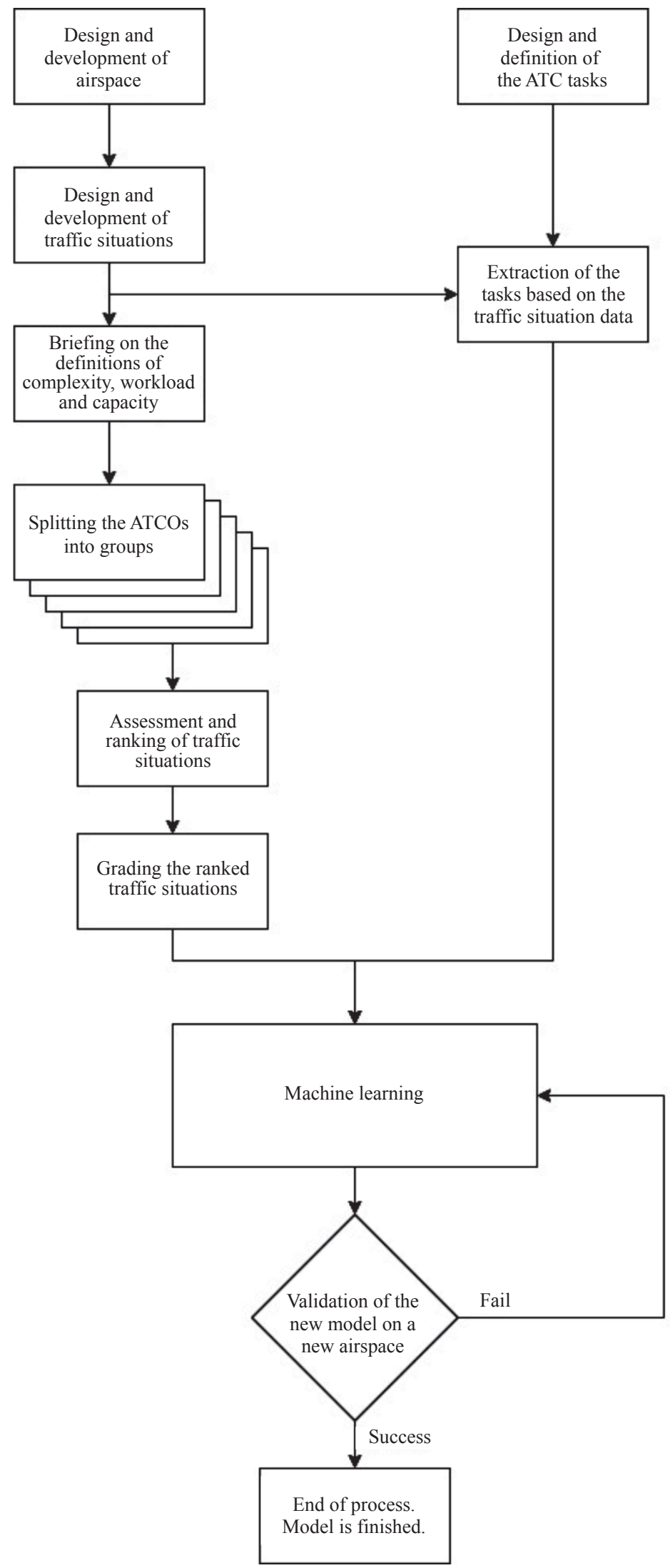

Figure 2-Methodology and plan of research 
Table 1 - Existing issues and new solutions for improved determination of air traffic complexity

\begin{tabular}{||l|}
\hline \multicolumn{1}{|c|}{ Existing issues } \\
\hline Schmidt [8] approached the problem of modelling controller \\
workload from the angle of observable controller actions. \\
Although the author conducted extensive surveys to deter- \\
mine appropriate weights and frequencies for various events, \\
this approach can only handle observable controller actions, \\
which makes this approach very limiting. \\
Authors in [12-14] developed 35 complexity indicators from \\
which only 17 are statistically significant, but later, they \\
concluded that these indicators are difficult to implement for \\
operational purposes. \\
Dervic and Rank [32] only used simple straightforward tasks \\
for terminal area to develop complexity model. The problem \\
with this approach is that they cannot be used on other traffic \\
and airspace other than the terminal area. \\
\hline
\end{tabular}

Kopardekar et al [16] have shown that the complexity indicator weights were not universal to all airspace sectors, i.e. they had to be adjusted in a sector by sector basis.

Radišić [25] concluded that ATCIT complexity assessment model needs to be adjusted and relearned for a new airspace.

Mogford [6] concluded that the air traffic complexity is a fundamental driver of workload but that the connection between complexity and workload is not straightforward; it is mediated by other factors, such as equipment quality, individual differences, and controller cognitive strategies. So, by putting the ATCOs to assess the complexity on a real time simulator, it can be difficult for them to distinguish the air traffic complexity from the workload that they are experiencing through other mediated factors such as human-machine interaction (HMI).

Kopardekar [17] used HITL simulations with air traffic controllers to assess the air traffic complexity.

Prevot and Lee [23] used HITL simulation runs in which the air traffic controllers had to give workload scores which were then compared with trajectory-based complexity value.

Radišić [25] also used the HITL simulation runs where air traffic controllers assessed the complexity on a scale from 1 to 7 .

Andraši [36] reported inconsistency when air traffic controllers assess air traffic complexity. The problem with inconsistency appears when the same controller grades the traffic situation that has a different complexity level with the same complexity scores. This could lead to an error when developing air traffic complexity model.

Gianazza [27-29] used 27 indicators to see how splitting and merging of the airspace sectors affect the complexity without consulting the air traffic controllers. The issue here is that authors used the historical data from opening, merging and closing of the sectors without looking into the reason behind the splitting of the sectors.

\section{New solutions}

The air traffic controller tasks are defined on the basis of the characteristics of the air traffic situation and do not depend on the person controlling the air traffic. Because of this, by detailed definition of air traffic controller tasks based on the pre-conflict resolution parameters, new model could calculate adequate complexity score. Additionally, detailed definition of the tasks will cover the parameters of the traffic in order that they would be applicable to other airspace and would not be tied to the specific air traffic controller.

Precise definition of ATCO tasks based on the pre-conflict resolution parameters cover traffic situations in more detail than a fixed number of indicators and could easily be implemented for operational purposes.

It is common for a person to link the learned experiences with the new ones. The same goes with air traffic controllers, where previously learned airspace knowledge and gained experience could cause an error in complexity assessment and scoring.

To mitigate this problem and to be able to use the model in different airspace ATCOs will be tested on the unfamiliar generic airspace. With this, we will avoid the error caused by already learned traffic situations and patterns of complexity.

To solve this problem ATCOs will assess the air traffic complexity of traffic situation by using paper static images. Images will be similar to radar image of the real ATCO working position. They will be given as much time as needed to assess air traffic complexity.

To solve this problem, ATCOs will be given two different traffic situations at the same time. During the experiment, the ATCOs will compare two traffic situations and evaluate which one is more complex, thus eliminating any inconsistences where ATCOs would grade different traffic situations with the same complexity score.

At the end, there would be a clear ranking of traffic situations from the lowest to the highest traffic complexity per tested ATCO.

During the complexity assessment by the air traffic controllers, other information will be collected as well, for example, the situation when ATCOs would want to split the sector based on the traffic complexity. Thus, the model will be allowed to adequately determine when the airspace should be divided or reorganized into another configuration based on the ATCO input of traffic complexity. 
calculate a sample size. There is no universal rule of thumb for the minimum sample size that can cover each individual situation and statistical model, but it is recommended to follow the statistical regularities mentioned earlier, as we are doing in this research. The defined number of air traffic controllers and the defined number of traffic situations are chosen to provide enough data to train the model for the purpose of this research. Afterwards, if the data would not provide enough statistical power, a larger data sample will be used. In that case, we will expand the number of traffic situations and the number of air traffic controllers.

Prior to the assessment, we will brief the ATCOs on the definitions of complexity, workload and airspace capacity to ensure that all of them have the same level of understanding of the air traffic complexity and that they understand what is expected of them during the assessment. During the ATCOs assessment, the ranking of the traffic situations will be done by merge sort algorithm [39]. Merge sort repeatedly splits a list of data into several sub-lists until each sub-list consists of a single component. Afterward, it merges those sub-lists in a way that results in a sorted list. Here, the input from the air traffic controller will be taken as a sort list rule. By ranking them in this manner, it will be impossible that two traffic situations have the same complexity score. Using this approach, we will eliminate the inconsistent assessment by the air traffic controllers, so that at the end of the validations, there will be a clear rank from the lowest to the highest complexity. Furthermore, to establish a clear grading system, the controllers will be asked to assess the traffic situations and give a complexity score, from 1 to 5 , where 1 will be the lowest and 5 will be the highest complexity score (Figure 2). Based on the controllers complexity ranking and scoring, we will assign linearly interpolated grades to each situation for each controller. Later on, all complexity scores will be used as target variables to train the model on how specific air traffic controller tasks (exploratory variables) contribute to air traffic complexity. We plan to use several statistical machine-learning approaches. One of the first approaches that will be used is linear regression and logistic regression models. Later on, depending on the $\mathrm{R} 2$ results we might test some non-linear models and compare them with the linear models. Cross-validation will be done for all the designed models in order to estimate out-of-sample situations. At the end, a real airspace will be used to verify the model. Air traffic controllers will assess air traffic complexity of the traffic situation within this real airspace, thus allowing us to make a correlation of the assessed complexity and the one determined by the new model. Figure 2 shows the complete overview of the methodology and plan of the research.

General overview of the existing issues in determining the air traffic complexity and how the novel model tackles these problems is depicted in Table 1 .

\section{CONCLUSION}

The problem of determining air traffic complexity, even after almost two decades of research on the global scale, has remained an unsolved challenge. Due to the increase of air traffic demand, this problem will be even more pronounced in the coming years. In this paper we give an overview of the most relevant literature of air traffic complexity research and present the main issues of the recent models and methods for determining air traffic complexity. For each issue we give a new solution that could significantly improve this field of research. Finally, we propose a preliminary communication on a novel methodology for future development of an air traffic complexity model based on the air traffic controller tasks. We assume that air traffic controller tasks based on the pre-conflict resolution parameters are the solution that will lead to the improvement of the air traffic complexity determination. Additionally, several other solutions, such as experiment design, static images of traffic situations and generic airspace, are important drivers of the future development of a new air traffic complexity model. We presume that this novel methodology could surpass all the shortcomings of the previous models.

BRUNO ANTULOV-FANTULIN, mag.ing.aeronaut. ${ }^{1}$

E-mail: bruno.antulov@fpz.unizg.hr

Dr. sc. BILJANA JURIČIĆ ${ }^{1}$

E-mail: biljana.juricic@fpz.unizg.hr

Dr. sc. TOMISLAV RADIŠIĆ ${ }^{1}$

E-mail: tomislav.radisic@fpz.unizg.hr

Dr. sc. CEM ÇETEK ${ }^{2}$

E-mail: ccetek@eskisehir.edu.tr

${ }^{1}$ Sveučilište u Zagrebu, Fakultet prometnih znanosti

Zavod za aeronautiku

Vukelićeva 4, 10000 Zagreb, Hrvatska

2 Tehničko sveučilište Eskişehir

Fakultet za aeronautiku i astronautiku

Zavod za kontrolu zračnog prometa

İki Eylül Kampüsü, Tepebaşı, Eskişehir 26470, Turska 


\section{ODRE円IVANJE KOMPLEKSNOSTI ZRAČNOG PROMETA - IZAZOVI I BUDUĆI RAZVOJ}

\section{SAŽETAK}

Kompleksnost zračnog prometa je jedan od glavnih faktora radnog opterećenja kontrolora zračnog prometa. Uz predviđen rast zračnog prometa, utjecaj kompleksnosti na radno opterećenje kontrolora zračnog prometa s vremenom će biti još izraženiji. Postojeći modeli i metode za određivanje kompleksnosti zračnog prometa pokazuju nedostatke i probleme koji i do danas predstavljaju neriješen izazov. U ovom radu dajemo pregled najrelevantnije literature na temu kompleksnosti zračnog prometa i poboljšanja koja se mogu postići u ovom području. Istražujemo postojeće probleme $i$ dajemo nova rješenja za poboljšanje određivanja kompleksnosti zračnog prometa. Dajemo preliminarni pregled budućeg razvoja nove metode za određivanje kompleksnosti zračnog prometa s ciljem dizajniranja novog modela kompleksnosti zračnog prometa koji je temeljen na zadaćama kontrolora zračnog prometa. Nova metoda koristi nova rješenja za poboljšanje postojećih modela kompleksnosti zračnog prometa, poput zadaća kontrolora zračnog prometa definiranih na parametrima prije rješavanja konflikta, dizajna eksperimenta, statičnih slika prometnih situacija i generičkog zračnog prostora.

\section{KLJUČNE RIJEČI}

kompleksnost zračnog prometa; kontrolor zračnog prometa; procjena; radno opterećenje; zadaće;

\section{REFERENCES}

[1] Performance Review Commission. Performance Review Report 2017. EUROCONTROL; 2018.

[2] Performance Review Unit. European ANS Performance Data Portal n.d. Available form: http://ansperformance. eu/ [Accessed 12 ${ }^{\text {th }}$ November 2018].

[3] STATFOR. EUROCONTROL Seven-Year Forecast February 2018; 2018.

[4] Meckiff C, Chone R, Nicolaon J-P. The Tactical Load Smoother for Multi-Sector Planning. $2^{\text {nd }}$ USA/Europe Air Traffic Management R\&D Seminar, 1-4 December 1998, Orlando, USA; 1998.

[5] Davis CG, Danaher JW, Fischl MA. The influence of selected sector characteristics upon ARTCC controller activities. Arlington: The Matrix Corporation; 1963.

[6] Mogford RH, Guttman JA, Morrow SL, Kopardekar P. The Complexity Construct in Air Traffic Control: A Review and Synthesis of the Literature. McKee City, NJ: CTA Incorporated; 1995.

[7] Hilburn B. Cognitive Complexity in Air Traffic Control: A Literature Review. Center for Human Performance Research; 2004.

[8] Schmidt DK. On Modeling ATC Work Load and Sector Capacity. Journal of Aircraft. 1976: 531-7.

[9] Hurst MW, Rose RM. Objective Job Difficulty,
Behavioural Response, and Sector Characteristics in Air Route Traffic Control Centres. Ergonomics. 1978;21(9): 697-708.

[10] Stein ES. Air traffic controller workload: An examination of workload probe. FAA; 1985.

[11] Laudeman IV, Shelden SG, Branstrom R, Brasil CL. Dynamic Density: An Air Traffic Management Metric. Moffett Field: Ames Research Center; 1998.

[12] Chatterji G, Sridhar B. Measures for air traffic controller workload prediction. $1^{\text {st }}$ AIAA, Aircraft, Technology Integration, and Operations, 16-18 Oct 2001, Los Angeles, CA, USA; 2001.

[13] Wyndemere. An Evaluation of Air Traffic Control Complexity. Boulder: 1996.

[14] Kopardekar P. Dynamic density: A review of proposed variables. Federal Aviation Administration; 2000.

[15] Kopardekar P, Magyarits S. Dynamic density: Measuring and predicting sector complexity [ATC]. Proceedings of the 21 $1^{\text {st }}$ Digital Avionics Systems Conference, 27-31 Oct. 2002, Irvine, CA, USA. IEEE; 2002. Available from: doi:10.1109/DASC.2002.1067920

[16] Kopardekar P, Magyarits S. Measurement and prediction of dynamic density. Proceedings of the $5^{\text {th }}$ USA/Europe Air Traffic Management R \& D Seminar. Vol. 139; 2003.

[17] Kopardekar P, Schwartz A, Magyarits S, Rhodes J. Airspace complexity measurement: An air traffic control simulation analysis. International Journal of Industrial Engineering: Theory, Applications and Practice. 2009;16(1): 61-70.

[18] Masalonis A, Callaham M, Wanke C. Dynamic Density and Complexity Metrics for Real-Time Traffic Flow Management. Budapest, Hungary; 2003.

[19] Klein A, Rodgers M, Leiden K. Simplified dynamic density: A metric for dynamic airspace configuration and NextGen analysis. Proceedings of the $28^{\text {th }}$ Digital Avionics Systems Conference (DASC): Modernization of Avionics and ATM-perspectives from the Air and Ground, 25-29 Oct. 2009, Orlando, FL, USA. IEEE; 2009. Available from: doi:10.1109/DASC.2009.5347539

[20] Bloem M, Brinton C, Hinkey J, Leiden K, Sheth K. A Robust Approach for Predicting Dynamic Density. Proceedings of the $9^{\text {th }}$ AIAA Aviation Technology, Integration, and Operations Conference (ATIO), 21-23 Sep. 2009, Hilton Head, SC, USA; 2009.

[21] Chaboud T, Hunter R, Hustache J, Mahlich S, Tullett P. Investigating the Air Traffic Complexity: Potential Impacts on Workload and Costs. Belgium: Eurocontrol; 2000.

[22] Performance Review Commission. Complexity Metrics for ANSP Benchmarking Analysis. Eurocontrol; 2006.

[23] Prevot T, Lee P. Trajectory-Based Complexity (TBX): A modified aircraft count to predict sector complexity during trajectory-based operations. 2011 IEEE/AIAA $30^{\text {th }}$ Digital Avionics Systems Conference, 16-20 Oct. 2011, Seattle, WA, USA. IEEE; 2011. Available form: doi:10.1109/DASC.2011.6096045

[24] Lee P, Prevot T. Prediction of Traffic Complexity and Controller Workload in Mixed Equipage NextGen Environments. Proceedings of the Human Factors and Ergonomics Society Annual Meeting. 2012;56: 100-4.

[25] Radišić T, Novak D, Juričić B. Reduction of Air Traffic 
Complexity Using Trajectory-Based Operations and Validation of Novel Complexity Indicators. IEEE Transactions on Intelligent Transportation Systems. 2017;18(11): 3038-48.

[26] Prandini M, Putta V, Hu J. Air traffic complexity in future Air Traffic Management systems. Journal of Aerospace Operations. 2012;1(3): 281-99.

[27] Gianazza D, Guittet K. Selection and evaluation of air traffic complexity metrics. Proceedings of the 2006 IEEE/ AIAA 25 $5^{\text {th }}$ Digital Avionics Systems Conference, 15-18 Oct. 2006, Portland, OR, USA. IEEE; 2006. p. 1-12. Available form: doi:10.1109/DASC.2006.313710

[28] Gianazza D. Forecasting workload and airspace configuration with neural networks and tree search methods. Artificial Intelligence. 2010; 174(7-8): 530-49. https:// doi.org/10.1016/j.artint.2010.03.001.

[29] Gianazza D. Smoothed traffic complexity metrics for airspace configuration schedules. Fairfax, United States; 2008.

[30] Lee K, Feron E, Pritchett A. Describing Airspace Complexity: Airspace Response to Disturbances. Journal of Guidance, Control, and Dynamics. 2009;32: 210-22.

[31] Wee HJ, Lye SW, Pinheiro J-P. A Spatial, Temporal Complexity Metric for Tactical Air Traffic Control. Journal of Navigation. 2018;71(5): 1040-54. Available from: doi:10.1017/S0373463318000255

[32] Rank A, Dervic A. ATC complexity measures: Formulas measuring workload and complexity at Stockholm TMA.
Linköping University; 2015.

[33] Wang H, Song Z, Wen R. Modeling Air Traffic Situation Complexity with a Dynamic Weighted Network Approach. Journal of Advanced Transportation. 2018;2018: Article ID 5254289. 15 p. Available from: doi:10.1155/2018/5254289

[34] Xiao M, Zhang J, Cai K, Cao X. ATCEM: A synthetic model for evaluating air traffic complexity. Journal of Advanced Transportation. 2016;50: 315-25. Available from: doi:10.1002/atr.1321

[35] Zhu X, Cao X, Cai K. Measuring air traffic complexity based on small samples. Chinese Journal of Aeronautics. 2017;30: 1493-505.

[36] Andraši P, Radišić T, Novak D, Juričić B. Subjective Air Traffic Complexity Estimation Using Artificial Neural Networks. Promet - Traffic\& Transportation. 2019;31(4): 377-86.

[37] Green SB. How many subjects does it take to do a regression analysis? Multivariate Behavioral Research. 1991;26: 499-510.

[38] Van Voorhis CRW, Morgan BL. Understanding Power and Rules of Thumb for Determining Sample Size. Tutorials in Quantitative Methods for Psychology. 2007;3(2): 43-50. Available from: doi:10.20982/tqmp.03.2.p043

[39] Goldstine HH, von Neumann J. Planning and coding of problems for an electronic computing instrument. John von Neumann Collected Work, Theory of Automata and Numerical Analysis. 1963;5: 152-214. 